\title{
A review of the proposed role of neutrophils in rodent amebic liver abscess models
}

\author{
Rafael Campos-Rodríguez ${ }^{1}$, Manuel Gutiérrez-Meza ${ }^{1,2}$, Rosa Adriana Jarillo-Luna ${ }^{1,2}$, \\ María Elisa Drago-Serrano ${ }^{3}$, Edgar Abarca-Rojano ${ }^{1}$, Javier Ventura-Juárez ${ }^{4}$, \\ Luz María Cárdenas-Jaramillo ${ }^{2}$, and Judith Pacheco-Yepez ${ }^{1, *}$ \\ 1 Sección de Posgrado e Investigación, Escuela Superior de Medicina, Instituto Politécnico Nacional, Distrito Federal, México \\ 2 Coordinación de Ciencias Morfológicas, Escuela Superior de Medicina, Instituto Politécnico Nacional, Distrito Federal, México \\ 3 Departamento de Sistemas Biológicos, Unidad Xochimilco, Universidad Autónoma Metropolitana, Distrito Federal, México \\ 4 Departamento de Morfología, Centro de Ciencias Básicas, Universidad Autónoma de Aguascalientes, Aguascalientes, México
}

Received 18 September 2015, Accepted 31 January 2016, Published online 15 February 2016

\begin{abstract}
Host invasion by Entamoeba histolytica, the pathogenic agent of amebiasis, can lead to the development of amebic liver abscess (ALA). Due to the difficulty of exploring host and amebic factors involved in the pathogenesis of ALA in humans, most studies have been conducted with animal models (e.g., mice, gerbils, and hamsters). Histopathological findings reveal that the chronic phase of ALA in humans corresponds to lytic or liquefactive necrosis, whereas in rodent models there is granulomatous inflammation. However, the use of animal models has provided important information on molecules and mechanisms of the host/parasite interaction. Hence, the present review discusses the possible role of neutrophils in the effector immune response in ALA in rodents. Properly activated neutrophils are probably successful in eliminating amebas through oxidative and non-oxidative mechanisms, including neutrophil degranulation, the generation of free radicals $\left(\mathrm{O}_{2}{ }^{-}, \mathrm{H}_{2} \mathrm{O}_{2}, \mathrm{HOCl}\right)$ and peroxynitrite, the activation of NADPH-oxidase and myeloperoxidase (MPO) enzymes, and the formation of neutrophil extracellular traps (NETs). On the other hand, if amebas are not eliminated in the early stages of infection, they trigger a prolonged and exaggerated inflammatory response that apparently causes ALAs. Genetic differences in animals and humans are likely to be key to a successful host immune response.
\end{abstract}

Key words: Amoebic liver abscess, Rodents, Neutrophil activation, Reactive oxygen and nitrogen species, Peroxynitrite, Neutrophil extracellular traps.

\begin{abstract}
Résumé - Une synthèse sur le rôle proposé des neutrophiles dans les modèles d'abcès hépatique du foie chez les rongeurs. L'invasion d'un hôte par Entamoeba histolytica, l'agent pathogène de l'amibiase, peut conduire au développement d'un abcès hépatique amibien (AHA). En raison de la difficulté d'explorer les facteurs dépendant de l'hôte et des amibes impliqués dans la pathogenèse de l'AHA chez les humains, la plupart des études ont été menées sur des modèles animaux (par exemple souris, gerbilles et hamsters). Les résultats histopathologiques montrent que la phase chronique de l'AHA chez l'homme correspond à la nécrose lytique ou liquéfiante, tandis que dans les modèles rongeurs on rencontre une inflammation granulomateuse. Cependant, l'utilisation de modèles animaux a fourni des informations importantes sur les molécules et les mécanismes de l'interaction hôte/parasite. Cette synthèse discute donc le rôle possible des neutrophiles dans la réponse immunitaire effectrice pendant l'AHA chez les rongeurs. Les neutrophiles correctement activés réussissent probablement à éliminer les amibes grâce à des mécanismes oxydatifs et non oxydatifs, y compris la dégranulation des neutrophiles, la génération de radicaux libres $\left(\mathrm{O}_{2}^{-}, \mathrm{H}_{2} \mathrm{O}_{2}, \mathrm{HOCl}\right)$ et de peroxynitrite, l'activation des enzymes NADPH-oxydase et myéloperoxydase, et la formation de pièges extracellulaires des neutrophiles. D'autre part, si les amibes ne sont pas éliminées au cours des premiers stades de l'infection, elles déclenchent une réponse inflammatoire prolongée et excessive qui provoque apparemment l'AHA. Les différences génétiques chez les animaux et les humains sont probablement la clé d'une réponse immunitaire réussie de l'hôte.
\end{abstract}

\footnotetext{
*Corresponding author: payejuca@prodigy.net.mx
}

This is an Open Access article distributed under the terms of the Creative Commons Attribution License (http://creativecommons.org/licenses/by/4.0), which permits unrestricted use, distribution, and reproduction in any medium, provided the original work is properly cited. 


\section{Introduction}

Because it is very difficult to study the pathogenesis of amebiasis in humans, several animal models have been employed to elucidate pathogenic mechanisms, immune response, and the host-parasite relation. Through the use of these models, important differences have been discovered between rodents and humans in the chronic phase of ALA [124]. The histopathology of the chronic phase of ALA in humans corresponds to lytic or liquefactive necrosis, whereas in rodent models there is granulomatous inflammation [2, 32, 124, 125]. Hepatic damage in hamsters and mice is caused by apoptosis and necrosis rather than the lytic necrosis found in humans in the chronic phase of the disease $[14,112,126]$. However, the information gathered on the pathogenesis of ALA in rodent models has been useful for understanding the effect of different host molecules and mechanisms in humans. The present review discusses the role of neutrophils in the development of ALA based mostly on studies with rodent models.

\section{The role of host and parasite genotypes in the development of amebiasis}

Invasive amebiasis, caused by the enteric pathogen E. histolytica, can lead to amebic colitis and ALA. These two disorders are associated with significant levels of morbidity and mortality worldwide [118]. Despite the numerous studies carried out to understand invasive amebiasis and its complications, the mechanisms by which amebas cause host tissue damage have still not been clearly identified. It is evident that both host and parasite genotypes as well as environmental factors (e.g., malnutrition) influence the development of the different forms of the disease (asymptomatic colonization, diarrhea, invasive colitis, liver abscess) [93]. In the hostparasite interaction, neutrophils seem to play a pivotal role in determining resistance or susceptibility.

\subsection{Genetic differences in susceptibility to Entamoeba histolytica infection}

Species differ in susceptibility to Entamoeba histolytica. Whereas these trophozoites produce liver abscesses in hamsters, gerbils, and some strains of mice, this is not the case in other species of mice or in rats and guinea pigs (even when larger inocula are used in the latter animals). In addition, within the context of a naturally provoked infection, E. histolytica only produces invasive lesions in the intestine of humans. Moreover, the majority of people infected with virulent $E$. histolytica do not develop symptomatic disease. This evidence suggests that there are genetic differences between susceptible and resistant species [24].

Indeed, associations have been found between MHC class II alleles and susceptibility [9, 10] or resistance to amebic liver abscess [50]. Also, one study showed an association between protection against intestinal amebiasis and an HLA class II allele or haplotype. However, there is no explanation mechanistically linking HLA class II genes and resistance or susceptibility to invasive amebiasis. It has been proposed that the presence or absence of a particular HLA class II allele could alter the response to amebic infection by changing the repertoire of proteins presented by $\mathrm{CD}^{+} \mathrm{T}$ cells [36].

The differences in susceptibility to $E$. histolytica between the sexes can also be understood in terms of genetic characteristics. Invasive amebiasis predominantly affects men, which is possibly due to sex-associated hormones or factors linked to the X-chromosome that may act, at least in part, by means of their effects on innate immunity [24]. Studies with animals support this idea. In a murine model, males are more susceptible to ALA development than females [63]. Resistance has been associated with NKT cells activated by the lipopeptidophosphoglycan from E. histolytica membranes (EhLPPG), leading to the production of IFN-gamma [64, 65]. Susceptibility in male mice was associated with the production of tumor necrosis factor alpha by monocytes and Kupffer cells [48].

\subsection{Parasite genotypes also influence infection outcomes}

E. histolytica strains are highly heterogeneous in relation to pathogenicity. Pathogenic and non-pathogenic strains differ in their ability to cause invasive disease, as well as in several biochemical and molecular criteria [15, 22, 24]. Similarly, the genotypes of E. histolytica parasite are significantly different in infected patients without symptoms, with diarrhea/dysentery, or with ALA [5]. Thus, only certain genotypes are capable of causing abscesses, likely due to genetic factors [93].

Many virulence factors of $E$. histolytica have been characterized, including Gal/GalNAc adherence lectin, cysteine proteases (CPs), arginase, amebapores, alcohol dehydrogenase, peroxiredoxin, cyclooxygenase 2 , and lipopeptidophosphoglycan (LPPG). One study showed that stable transfectants of virulent $E$. histolytica were strongly inhibited in their cytopathic activity, cytotoxic activity, and ability to induce the formation of amebic liver abscess in hamsters when the expression of the $\mathrm{Gal} / \mathrm{GalNac}$ lectin $35 \mathrm{kDa}$ subunit was inhibited by antisense RNA. This suggests that the $35 \mathrm{kDa}$ subunit may have a function in amebic pathogenicity [7]. Recently, Matthiesen et al. [70] reported that papain-like cysteine peptidase (CP) genes of E. histolytica are differently expressed during ALA formation in distinct rodent models. Non-pathogenic ameba clone A1 that did not induce ALA was transfected, enabling overexpression of CPs that are expressed at high levels during ALA formation. Overexpression of ehcp-b8, -b9, and -c13 restored the pathogenic phenotype of non-pathogenic clone A1, which shows the important role of this molecule in the pathogenicity of E. histolytica. Further studies are needed to identify how other specific genes participate in the pathogenesis of amebiasis $[69,93]$.

\section{Amebic liver abscess: the possible relation of amebic mechanisms and host inflammation}

After entering the host through the digestive tract, amebas arrive in the liver through the blood flow. In this organ, the mechanisms of amebic adherence to immune cells are vital 


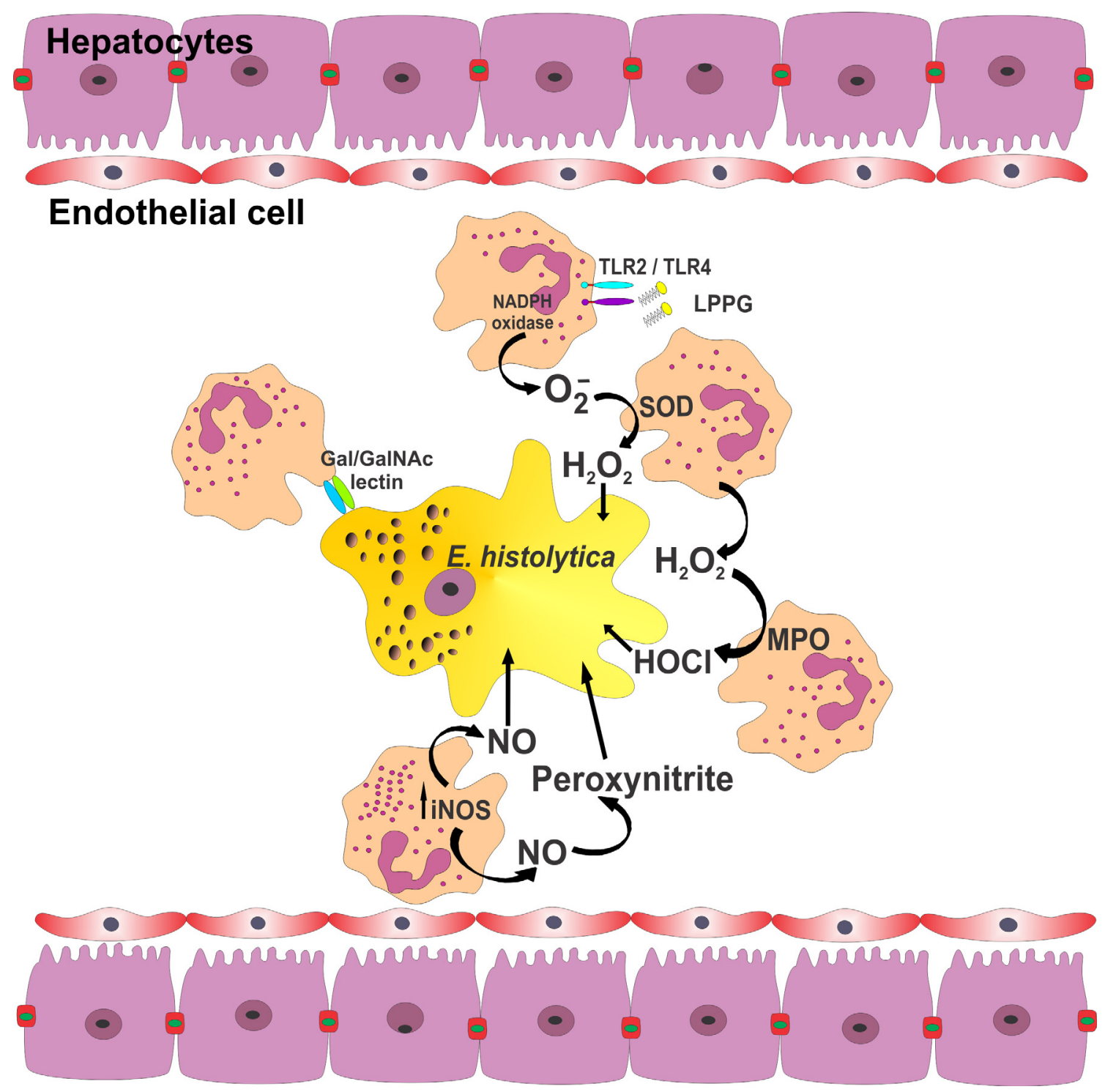

Figure 1. The initial contact between the lectin and neutrophil receptors promotes CR 3 expression by neutrophils, and then the interaction of this molecule with $\mathrm{iC} 3 \mathrm{~b}$ induces neutrophil degranulation. It is likely that neutrophils are activated due to the recognition by TLR-2 and TLR-4 of lipopeptidophosphoglycan (LPPG) from E. histolytica. Activated neutrophils undergo an "oxidative burst" that results in an increased production of superoxide $\left(\mathrm{O}_{2}^{-}\right)$by the NADPH-oxidase system. Superoxide dismutase (SOD) rapidly converts $\mathrm{O}_{2}{ }^{-}$to hydrogen peroxide $\left(\mathrm{H}_{2} \mathrm{O}_{2}\right.$, a highly oxidizing agent), and to the substrate of MPO for the formation of hypochlorous acid (HOCl). During this oxidative burst, neutrophils express high levels of iNOS, causing an increase in $\bullet N O$. Another powerful oxidant is peroxynitrite, formed by the reaction of $\bullet \mathrm{NO}$ and $\mathrm{O}_{2} \bullet-$.

for survival of the pathogen. In the susceptible hamster model of ALA, E. histolytica amebas were found in the portal vein of the liver, in the lumen of small branches of the portal vein, and in central veins at 30 min post-inoculation. After $1 \mathrm{~h}$, trophozoites were randomly located in the sinusoids throughout the hepatic lobules [125].

Hence, during the first hour after E. histolytica enters the digestive tract, amebic mechanisms (adhesion, cytolysis, and cytopathogenicity) are vital for the trophozoite to be able to survive and proliferate. Of the toxic molecules secreted by amebas, cysteine proteases are particularly important. They are capable of producing a cytotoxic effect on host cells, modulating the cell-mediated immune response (e.g., leukocytes), and carrying out proteolysis of the host extracellular matrix $[37,51,54,93,117,118]$. A question that arises is whether these mechanisms only enable $E$. histolytica trophozoites to survive in a hostile environment, or if they also create ALA. To answer this question, two critical time periods must be considered: the early amebic invasion of the liver (from 1 to $24 \mathrm{~h}$ post-infection) and the time of ALA development (3-7 days post-infection).

During an amebic invasion of the liver, phagocytosis and cytopathogenicity can take place in the host liver parenchyma whether or not cysteine proteases are present [52, 79] (Fig. 1). Indeed, during the later stages of ALA, the majority of host cells in contact with amebas appear to be undamaged [25], 
suggesting that liver tissue damage at this stage is not directly related to amebic mechanisms. In this regard, another study by Olivos-Garcia et al. [80] showed that in the hamster model of amebic invasion of the liver, an immunosuppressor drug, cyclosporine, inhibits tissue damage. Under these conditions, the presence of undamaged parasites was accompanied by few if any leukocytes. Other studies have suggested that the massive lysis of neutrophils by virulent amebas exacerbates host tissue damage in amebic liver abscess [79, 125]. These reports provide evidence that in the acute and chronic phases of ALA, host tissue damage is caused more by the immune response than by amebic mechanisms.

In a gerbil model of ALA, early lesions were accompanied by an acute inflammatory response, mainly constituted by a large number of neutrophils and eosinophils. There was widespread lysis of these immune cells accompanied by the proliferation of ALA. The authors asserted that in the gerbil model, the fact that the acute inflammatory response is inefficient in destroying trophozoites allows for the development of ALA, a process that is aggravated by the lytic secretory products of both inflammatory cells and necrotic areas [27].

Since liver tissue damage during amebiasis is likely to be a downstream event in regard to amebic virulence factors, the host immune response must be explored to determine the mechanisms of ALA. It is known that both the innate and adaptive immune responses can contribute to the protection of the host during amebic invasion. Interestingly, several studies with animal models have demonstrated that virulent amebas can be eliminated within a few hours of infection, which could only be explained by the innate response [53, 109, 128].

Shibayama injected inflammatory substances (incomplete Freund's adjuvant and mineral oil) into the hamster peritoneum, and animals were then challenged with $E$. histolytica trophozoites, demonstrating protection against the development of ALA [113]. The authors concluded that non-specific stimulation of peritoneal exudate cells, mainly constituted by neutrophils and macrophages, prevented amebic invasion of the liver.

Hence, it has been proposed that resistance to amebic invasion is the result of an efficient innate immune response [53, $113,128]$ and that susceptibility is a consequence of the inadequacy of the same [25, 117, 125]. Regarding susceptibility, abundant evidence supports the idea that a chronic inflammatory response is one of the principal causes of host tissue damage $[24,25,113,131]$. Indeed, virulent $E$. histolytica trophozoites cause little or no liver tissue damage in hamsters in the absence of inflammatory cells [79, 90].

For example, leukopenic hamsters with no inflammatory cells (after whole body radiation at 800 rads) were infected with amebas, which rapidly disappeared from the liver without producing any lesions [79]. Likewise, the lack of an inflammatory response to amebas in the hamster liver results in the early disappearance of E. histolytica trophozoites from the parenchyma and no liver damage [90].

In summary, inflammation appears to be pivotal and amebic molecules dispensable for the formation of liver abscesses during amebiasis. Since neutrophils are the first elements of the inflammatory infiltrate to arrive at sites of amebic presence, as well as the most numerous cells in the early stages of the inflammatory response (1-24 h post-inoculation), the aim of the current review was to explore the mechanisms of activated neutrophils that may contribute to the elimination of E. histolytica.

\section{Anti-amebic activity of neutrophils}

Neutrophils have long been recognized as the most important killers of invasive microorganisms in the body [6, 77, 85, $108,115,116,122]$. They are not only the most abundant cells at inflammatory sites, but also the first to interact with invasive amebas [27, 53, 125]. In animal models of amebic liver abscess, neutrophils have been found in the liver from $30 \mathrm{~min}$ to a few hours after inoculation with $E$. histolytica $[27,53,123$, 125]. Moreover, neutrophils have proven to be effective killers of ameba. An in vitro study compared activated and unactivated (with rIFN- $\gamma$ and rTNF- $\alpha$ ) human neutrophils, finding that the former show a $97 \%$ increase in amebic killing. Neutrophils enhance their amebicidal activity after cytokine treatments [35].

In a study in which amebas were inoculated in Balb/c and $\mathrm{C} 3 \mathrm{H} / \mathrm{HeJ}$ mice (resistant animal models of ALA), neutrophils and other immune cells were able to limit the amebic lesion by the fourth day [53]. The absence of neutrophils in another in vivo study pointed to the important role of these immune cells in controlling the size of ALA. With a severe combined immunodeficient (SCID) mouse model [109], animals were neutrophil-depleted with monoclonal anti-neutrophil antibodies RB68C5. After infection with E. histolytica trophozoites, these neutrophil-depleted mice had larger amebic liver abscesses at early stages than control animals (without depleted neutrophils). Histological analysis showed that neutrophil-depleted mice presented an absence of inflammatory cells surrounding the necrotic area. This study supports the idea that neutrophils play a key role in controlling amebic liver abscess in SCID mice. Another study corroborated the same idea [128], reporting significantly larger ALAs in neutrophildepleted mice. Neutrophil activation can set in motion various mechanisms of the inflammatory response, including the activation of other immune components. One of these components is mononuclear cells, which are apparently the principal actors that combat abscess formation during the chronic stage of ALA.

Although neutrophils seem to be important for eliminating invading amebas, they can also apparently contribute to host tissue damage. This seemingly double-edged role of neutrophils, evidenced by various studies, seems to depend on the time frame of an amebic invasion. One such study reported that after polymorphonuclear leukocytes surrounded amebas in the liver, the lysis of liver parenchymal tissue continued [125], evidently not the result of amebic mechanisms. Other leukocytes underwent massive destruction, which favored greater necrosis, hemorrhaging of parenchymal tissue, and the formation of ischemic areas [79, 125].

A study carried out with C57BL76 mice reported that neutrophils were the first and majority of immune cells to infiltrate the liver on day 1 of an amebic invasion [48]. In the chronic stage of amebiasis (3-7 days post-inoculation), the diffuseness of neutrophil staining suggested neutrophil cell death. At this 
time, the inflammatory infiltrate was represented principally by macrophages. The authors then depleted neutrophils from another set of mice by using anti-Ly6G or anti-GR1antibodies, and inoculated the animals with E. histolytica. Anti-Ly6G recognizes the neutrophil-specific cell surface molecule Ly6G and selectively depletes neutrophils. Compared with wild type mice, neutrophil depletion with anti-Ly6G led to a slight but not significant reduction in the abscess size. The authors also used anti-GR1, which recognizes Ly6C. This receptor is expressed on both neutrophils and monocytes. Depletion of immune cells with the anti-GR1 antibody caused a significant decrease in ALA size on day 3 post-inoculation.

The authors concluded that neutrophils do not have a beneficial or protective role in ALA, but in fact contribute to liver damage. We would argue that the effect of the Ly6G or antiGR1 antibodies should have been measured from 1 to $24 \mathrm{~h}$ post-inoculation, the time period that neutrophils probably have their most effective action during an amebic infection. The fact that they found evidence of neutrophils contributing to liver damage at day 3 post-inoculation is in agreement with the processes we have described corresponding to the chronic phase of ALA. The formation of the abscesses is accompanied by the massive lysing of neutrophils.

On the other hand, the same authors [48] concluded that Ly6C + mononuclear cells but not Ly6G+ neutrophils are critical cell mediators of tissue destruction during ALA formation. However, the anti-GR1 antibody depletes both neutrophils and monocytes. Therefore, the decrease in ALA size could be attributed to the additive effect of both these immune cell types. Moreover, the decrease in the size of ALA after pretreatment with the anti-GR1 antibody is to be expected, as it leads to a decrease in monocytes, which are the principal immune molecules participating in the inflammatory response during the stages of chronic inflammation on day 3 .

\section{Neutrophil effector mechanisms}

It seems that adequate or inadequate activation of neutrophils is one of the key factors in determining resistance or susceptibility to E. histolytica, an idea supported by many studies $[25,53,88,90,125,128]$. Indeed, it has been shown that neutrophils are either activated or inactivated upon interacting with trophozoites and their molecules [35, 44, 46].

Lipophosphoglycan-like (LPG) and lipopeptidophosphoglycan (LPPG) glycosylphosphatidylinositol-linked molecules of E. histolytica probably behave like pathogen-associated molecular patterns (PAMPs) that are recognized by TLR-2 and TLR-4, thus leading to the activation of neutrophils. This is known to occur with human monocytes and dendritic cells $[66,67,131]$.

Activated neutrophils can eliminate non-pathogenic amebas in individuals who are susceptible to pathogenic strains $[46,75,117,119]$, and they produce cytokines that could influence or determine the evolution of the immune response against diverse pathogens including E. histolytica [53]. These cytokines have a variety of functions, such as stimulating the production of reactive oxygen species (ROS), activating NF-kB, and increasing neutrophil degranulation [26] (Fig. 2).
It is likely that activated neutrophils are attracted to sites of amebic invasion by various phenomena, including the chemotactic activity of amebic membrane proteins [28, 44, 58, 105] as well as C5a and C3a fragments produced by activation of the complement on the amebic surface [46, 98, 99]. Neutrophils also likely follow the trail of chemokines secreted by cells exposed to E. histolytica [46].

These immune cells make close contact with pathogenic and non-pathogenic strains of E. histolytica, showing higher chemotaxis in vitro toward live pathogenic amebas [105]. The interaction between the $260 \mathrm{kDa} \mathrm{Gal} / \mathrm{GalNAc}$ lectin of $E$. histolytica and neutrophil receptors may initially mediate the ameba-host encounter [23, 31, 97], possibly leading to greater expression of CR3 molecules and thus the formation of neutrophil conglomerates around the ameba by homotypical recognition among molecules.

Whatever the exact mechanism may be, the formation of neutrophil conglomerates is probably pivotal to the amebicidal activity of the immune response. In one study [53], Balb/c and $\mathrm{C} 3 \mathrm{H} / \mathrm{HeJ}$ mouse strains (resistant animal models) were inoculated with $E$. histolytica to analyze the cellular immune response in these animals. The results show that amebas were surrounded by neutrophils containing nitric oxide synthase (iNOS) as well as by macrophage leukocytes. Neutrophils, macrophages, and other immune cells limited the amebic lesion and eliminated the parasites by the fourth day [53]. It has also been found that trophozoites are surrounded by neutrophils in hamsters and gerbils (susceptible animal models) [27, 125].

Several studies from ALA models have shown that the aggregation of inflammatory cells, among them neutrophils, is the first line of defense against amebas in ALA [63, 125, 129]. Once neutrophils aggregate with other inflammatory cells, they form conglomerates that surround amebas. Under these conditions, it is known that neutrophils attack amebas by the release of oxidative molecules (superoxide, peroxide, $\mathrm{NO}$, and peroxynitrite) as well as with non-oxidative mechanisms (degranulation, release of MPO) [35, 83, 109, 128]. Apart from their direct role in surrounding and attacking amebas, neutrophils also influence the function of other immune cells. On the other hand, one mechanism that can be discarded in regard to E. histolytica is phagocytosis, because neutrophils (with a diameter of 12-15 $\mu \mathrm{m}$ ) cannot phagocyte amebas (with a diameter of $20-40 \mu \mathrm{m})$.

\subsection{Oxidative mechanisms}

\subsubsection{Superoxide and peroxide}

Activated neutrophils undergo an "oxidative burst", during which time the large NADPH-oxidase complex assembles at the phagosomal and plasma membranes and transfers electrons to molecular oxygen, yielding superoxide $\left(\mathrm{O}_{2}{ }^{-}\right)$. Through catalysis induced by superoxide dismutase (SOD), $\mathrm{O}_{2}{ }^{-}$is rapidly converted to hydrogen peroxide $\left(\mathrm{H}_{2} \mathrm{O}_{2}\right)$. This molecule is both a highly oxidizing agent and the substrate of MPO. The latter molecule transforms $\mathrm{H}_{2} \mathrm{O}_{2}$ into hypochlorous acid ( $\mathrm{HOCl})$, which is the most bactericidal oxidant of neutrophils [47, 71, 77, 107, 122, 127] (Fig. 1). 


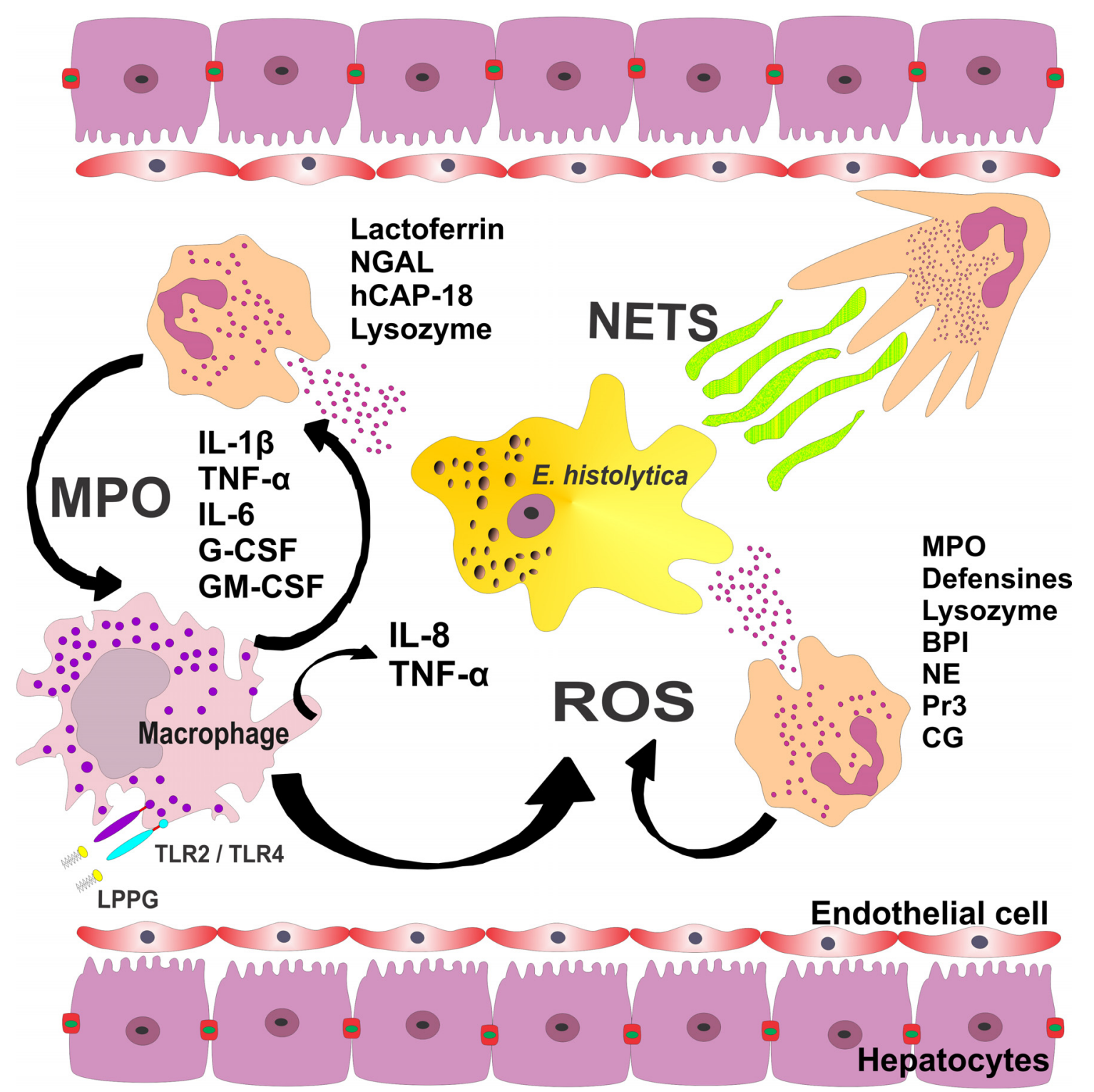

Figure 2. Activated neutrophils provide signals for the activation and maturation of macrophages, which in turn release IL-1 $\beta$, TNF- $\alpha$, G-CSF, and GM-CSF. These cytokines extend the life span of neutrophils at sites of inflammation. The interaction of lipopeptidophosphoglycan (LPPG) with TLR-2 and TLR-4 results in the activation of NF-kappa B and the release of IL-8, IL-10, IL-12p40, and TNF- $\alpha$ from human macrophages. Activated neutrophils enhance the production of reactive oxygen species (ROS), activating NF-kB and increasing neutrophil degranulation. Primary granules contain MPO, defensins, lysozyme, bactericidal/permeability-increasing protein (BPI), neutrophil elastase (NE), proteinase 3 (PR3), and cathepsin G (CG). Secondary granules are characterized by the presence of lactoferrin, neutrophil gelatinase-associated lipocalin (NGAL), human cationic antimicrobial protein 18 or cathelin (hCAP-18), and lysozyme. MPO can bind to monocytes, which might lead to the production of ROS and proinflammatory cytokines. Another function of neutrophils is the formation of neutrophil extracellular traps (NETs), composed of DNA bound with antimicrobial components (e.g., bacterial permeability-increasing protein, myeloperoxidase, elastase, lactoferrin). NET formation may have an important role in combating amebas.

It is possible that large quantities of $\mathrm{O}_{2}^{-}$and $\mathrm{H}_{2} \mathrm{O}_{2}$ are produced during the ameba-neutrophil interaction (Fig. 1). Several studies have indicated that $\mathrm{H}_{2} \mathrm{O}_{2}$ effectively kills Entamoeba. However, virulent $E$. histolytica is more resistant to $\mathrm{H}_{2} \mathrm{O}_{2}$ than non-virulent strains and species such as $E$. histolytica Rahman $[30,41,42,76,95]$.

Inflammatory cells reportedly release reactive oxygen species (ROS) and reactive nitrogen species (RNS) that kill pathogens [107]. However, PMNs are able to fulfill their function with both normal and defective production of ROS [74], which casts a doubt on whether these free radicals contribute directly and significantly to amebic killing in vivo. It is possible that ROS are only activators of granule proteins or other effector molecules.

The generally accepted view is that the system of NADPH oxidase promotes microbial killing through the generation of ROS and the activity of MPO. An alternative concept is that the main function of NADPH oxidase is to drive ion fluxes 
across the vacuolar membrane and to adjust the $\mathrm{pH}$ and ionic composition within the vacuole. In the case of amebiasis, either of these conditions would optimize the killing of amebas and regulate the digestive function of enzymes (e.g., elastase and cathepsin G) that could be released into the vacuole from the cytoplasmic granules [100, 107, 108]. In this way, the largely cationic microbicidal enzymes released would be made soluble by dissociation from the sulfated negatively charged granule matrix in an environment with a $\mathrm{pH}$ favorable for optimal activity [121]. In brief, it is possible that the predominant function of NADPH oxidase is to optimize conditions for the efficient function of the granule enzymes in the phagocytic vacuole (Fig. 2).

\subsubsection{Nitric oxide}

It has been demonstrated that $\mathrm{NO}$ is involved in amebicidal mechanisms of neutrophils and macrophages. For example, nitric oxide synthase (NOS) activity has been reported to be an important molecule for the control of hepatic amebiasis in immunocompetent mice [53,110]. Neutrophils have high expression of iNOS, especially when in contact with amebas. However, this expression is less than that of macrophages. On the other hand, the abundance of neutrophils in acutely inflamed tissue [53] may compensate for this lower expression.

Several studies have explored the role of iNOS and NO in the immune response to E. histolytica. For example, severe combined immunodeficiency (SCID) mice and iNOS knockout mice were employed to determine the in vivo role of IFN $\gamma$ and NO in host defense against amebic liver abscess formation [110]. SCID mice were genetically engineered to assure the absence of the IFN $\gamma$ receptor chain. The role of NO was assessed with knockout mice, in which the gene coding for iNOS was disrupted. When inoculated with amebas, the SCID and knockout mice developed larger ALAs than SCID control mice, showing that IFN $\gamma$ and iNOS play a role in innate immune protection against the development of ALA, probably by stimulating NO production in neutrophils. Although the stimulus that induces iNOS expression in neutrophils is still unknown, it could be similar to that described in macrophages, where the interaction of bone marrow monocytes with the Gal/ GalNAc lectin of E. histolytica induces the synthesis of TNF. This cytokine and TGF- $\beta 1$ stimulate IFN $\gamma$-primed macrophages to produce NO [62].

Nevertheless, it is likely that the role of NO in combating amebas is not direct. Even though in the serum of hamsters (susceptible model) iNOS mRNA expression and NO levels are greater with liver abscesses than in healthy animals [82, 94], the amebas continue to survive and proliferate (Fig. 1). Curiously, hepatic tissue damage was found to be reduced or prevented with the administration of nitric oxide synthase inhibitors [82]. Regarding the high concentrations of NO that exist during the development of ALA, trophozoite resistance to this molecule has been evidenced in vitro [96] and in vivo [82, 94] (see Sect. 6).

E. histolytica can probably resist the destructive action of $\mathrm{NO}$ and ROS because these trophozoites express high levels of antioxidant proteins, such as peroxiredoxin, flavoprotein A, superoxide dismutase, and rubrerythrin $[18,20,21,25,30,68]$.
Moreover, the blood flow to necrotic areas is reduced or blocked. Thus, at these sites the scarce supply of oxygen results in lower concentrations of NO and ROS.

\subsubsection{Peroxynitrite}

It is generally accepted that the system of NADPH oxidase and $\mathrm{H}_{2} \mathrm{O}_{2}$ promotes microbial killing through the activity of myeloperoxidase. In a similar manner, NO may promote microbial killing mainly through the formation of peroxynitrite [84]. Although not a free radical, peroxynitrite is a powerful oxidant. The peroxynitrite anion (ONOO-), a short-lived oxidant species, is produced by the reaction of the nitric oxide $(\bullet \mathrm{NO})$ and superoxide $(\mathrm{O} 2 \bullet-)$ radicals at diffusion-controlled rates [120]. NO is produced by NOS and $\mathrm{O}_{2}$ by NADPH oxidase. Therefore, the synthesis of peroxynitrite occurs in places where both these substrates are found, such as phagocytes (neutrophils, monocytes, macrophages, dendritic cells, mast cells) and activated endothelial cells [120].

To be able to survive and provoke an uncontrolled inflammatory response, trophozoites would require a better defense system against peroxynitrite than that of the susceptible host. There are two general mechanisms through which $E$. histolytica could protect itself against peroxynitrite: prevention (inhibition and scavenging of precursors) and interception (decomposition of peroxynitrite into non-toxic molecules) [11, 57].

\subsection{Non-oxidative mechanisms}

\subsubsection{Granules}

It is not known whether ROS contribute directly to amebic killing in vivo or are only activators of granule proteins, which are oxygen-independent effectors located in four types of granules in neutrophils: primary (azurophilic), secondary (specific), tertiary (gelatinase), and secretory vesicles. All of these granules contain a surplus of peptides and proteins that directly or indirectly kill microbes.

Azurophilic granules (peroxidase-positive or primary granules) contain myeloperoxidase (MPO), defensins, lysozyme, bactericidal/permeability-increasing protein (BPI), and a number of serine proteases, including neutrophil elastase (NE), proteinase 3 (PR3), and cathepsin G (CG). These granules function as the primary repository for the molecular weaponry of neutrophils. Secondary granules are characterized by the presence of a glycoprotein (lactoferrin) and several antimicrobial compounds, including neutrophil gelatinase-associated lipocalin (NGAL), human cationic antimicrobial protein 18 or cathelin (hCAP-18), and lysozyme [61]. Hence, through enzymes and cationic antimicrobial peptides, neutrophils could participate in amebic destruction as well as in the recruitment of cells that participate in both the innate and the specific immune responses [29] (Fig. 2).

Tertiary granules contain few antimicrobials, but they serve as a storage location for a number of metalloproteases, such as gelatinase and leukolysin. Secretory vesicles, also commonly considered part of the neutrophil granule, contain predominantly plasma-derived proteins such as albumin. The membrane 
of secretory vesicles serves as a reservoir for a number of important membrane-bound molecules employed during neutrophil migration [6, 16, 71, 77, 127].

Granules contain three main types of antimicrobials: (a) cationic peptides and proteins that bind to microbial membranes, (b) enzymes, and (c) proteins that deprive microorganisms of essential nutrients. At the inflammatory site, granules in the activated neutrophils are mobilized and fuse with either the phagosome or the plasma membrane, releasing their potent antimicrobials into the affected tissue [6, 77].

Little is known about the participation of these antimicrobial granular components in the destruction of amebas. They perhaps make contact with amebas through the extracellular degranulation of neutrophils and/or the lysis of neutrophils by $E$. histolytica. However, most granular components require activation by enzymes (serine proteases: cathepsin, elastase, and proteinase 3) that are not present in inflamed tissue $[12,107]$. Therefore, one granular component - MPO, an enzyme that works extracellularly - could be of particular importance.

\subsubsection{Myeloperoxidase}

Although neutrophils are too small to phagocytize E. histolytica, there is abundant evidence that they do indeed surround these pathogenic invaders [27, 33, 53, 88, 90, 125]. In this walled-off space, neutrophils could release $\mathrm{HOCl}$, an amebicidal molecule produced by the MPO enzyme.

MPO is a cationic enzyme located in the primary azurophilic granules of neutrophils and immature monocytes $[47,55,56]$. When released by neutrophils, MPO binds to monocytes that express mannose receptors [111], which might lead to the production of reactive oxygen species (ROS) and proinflammatory cytokines (i.e., TNF- $\alpha$, IL-1, IL-6, IL-8, and GM-CSF) [59]. Whereas inactive MPO is capable of inducing great quantities of pro-inflammatory cytokines, active MPO is more efficient for ROS production [40, 43, 60] (Fig. 2).

MPO uses the $\mathrm{H}_{2} \mathrm{O}_{2}$ produced by neutrophils to oxidize chloride ions and produce the highly cytotoxic $\mathrm{HOCl}$ (see Sect. 4.1.1). For the same purpose, it may use the SOD and NADPH flavin oxidoreductase produced by trophozoites, as occurs in other illnesses [47, 56, 71, 77, 91, 107, 127]. One study showed that hamster MPO binds to the surface of $E$. histolytica in vitro, causing important morphological and ultrastructural alterations and culminating in complete amebic destruction [83]. Thus, $\mathrm{HOCl}$ can in fact damage and kill trophozoites, indicating that MPO could indeed play an essential role in the innate immune response against $E$. histolytica $[47,71,107]$. Apart from provoking alterations in nuclear morphology and disturbances in the plasma membrane, MPO causes an increase in the number of vacuoles in the cytoplasm and a decrease in the presence of glycogen. Through its oxidative activity, $\mathrm{HOCl}$ produced by MPO modifies proteins, lipids, and DNA, and distorts the intracellular redox balance by depleting physiological antioxidants, such as ascorbate and glutathione [56].

A very recent study in our laboratory evaluated the behavior of MPO in Balb/c mice (resistant model) exposed to hepatic amebiasis. The MPO protein was observed in neutrophils present in the hepatic parenchyma, especially in inflammatory foci with damaged Entamoeba histolytica trophozoites. Moreover, the in situ enzymatic activity of MPO increased significantly as the time of infection elapsed. Based on these results, we suggest that this enzyme could destroy amebas and therefore play an important role in the resistance mechanisms of Balb/c mice against hepatic infection (unpublished data).

Based on the evidence presented here, we propose a model of the amebicidal effect of MPO. In the first stage of the amebic invasion, E. histolytica trophozoites spread through the bloodstream to the liver and are exposed to a high oxygen partial pressure and to circulating neutrophils $[3,46,106]$. Neutrophils and other immune cells then rapidly accumulate around the trophozoites [53, 125] and release $\mathrm{HOCl}$ (produced by MPO and $\mathrm{H}_{2} \mathrm{O}_{2}$ ) thus inducing toxicity. Moreover, it is possible that MPO is released into the extracellular fluid by leakage during cell lysis or by the exposure of neutrophils to a variety of soluble stimuli [55] and that it could be more efficient in the area of contact between immune cells and the amebic membrane. The activity of the MPO- $\mathrm{H}_{2} \mathrm{O}_{2}-\mathrm{HOCl}$ system seems to be an important mechanism by which the innate immune response prevents the invasion of E. histolytica [83, 113].

\subsubsection{Neutrophil extracellular traps (NETs)}

In addition to phagocytizing bacteria, secreting cytotoxic molecules, and affecting other immune molecules, another function of neutrophils was identified in 2004: the formation of NETs [71]. Due to intense efforts made since then, it is now known that NETs have a microbicidal function and possibly form a physical barrier that avoids the further spread of bacteria $[6,17,49,85,107,122,130]$. Composed of DNA bound with antimicrobial components (e.g., bacterial permeability-increasing protein, myeloperoxidase, elastase, and lactoferrin) [49, 122], these networks of extracellular fibers are able to capture gram-positive and gram-negative bacteria [130].

It has been shown that NETs released from neutrophils can trap parasites such as Leishmania sp., Plasmodium falciparum, and Toxoplasma gondii [1, 13, 39, 45, 49]. Although the molecular mechanism of NET formation is still unclear, it is known that MPO, NADPH oxidase, and elastase are required $[38,49,73,85-87,122]$. Some pathogens that are too large to be phagocytized, such as fungal hyphae, are trapped by NETs [6, 127]. This may also be the case for helminths and amebas (Fig. 2). Although NET formation had not previously been described in the literature as a response to E. histolytica, recent work in our laboratory has shown that the release of these structures participates in the interactions between human PMN cells and E. histolytica trophozoites, and that MPO is present in them (unpublished work).

\section{Defense mechanisms of amebas}

The capacity of E. histolytica to provoke ALA has been considered for many decades to be primarily related to amebic mechanisms (adhesion molecules, proteases, membrane proteins, and amebapores). Cysteine proteases (especially those located on the surface of E. histolytica) can destroy neutrophils and macrophages and degrade the granular proteins of 
neutrophils (Fig. 1). However, several findings suggest that cysteine proteinases either are not involved or play a minor role in tissue damage [25, 92].

The amebic secretion of serine protease inhibitors (serpins) seems to be another defense mechanism of $E$. histolytica. These molecules inhibit neutrophil serine proteases (e.g., proteinase 3, cathepsin, and elastase, known collectively as serprocidins) and there is evidence of their activity in E. histolytica. It is known that the sequenced Entamoeba genome contains serpin genes [102] and that serpins located in the cytoplasm of E. histolytica are secreted in the presence of specific mammalian cells. It has been reported that serpin alpha 1-antitrypsin inactivates neutrophil elastase (NE) when it is no longer necessary [6] and that one serpin of E. histolytica - cathepsin $G$ - inactivates a serine proteinase secreted by human neutrophils [101].

Additionally, several enzymes of E. histolytica can inhibit the oxidative response of neutrophils [4, 8, 104]. For instance, neutrophils have an iron-containing superoxide dismutase $[18,19]$ and a bifunctional NADPH flavin oxidoreductase [21] that transform superoxide anions to $\mathrm{H}_{2} \mathrm{O}_{2}$. However, this molecule can be reduced and detoxified by a surface peroxiredoxin of E. histolytica [20, 30, 34]. Moreover, virulent amebas exposed to great concentrations of $\mathrm{O}_{2}$ are able to reduce these molecules as well as $\mathrm{H}_{2} \mathrm{O}_{2}$ by the reactivation of a reversible pyruvate, the ferredoxin oxidoreductase (PFOR) enzyme, and therefore show high resistance to increased levels of $\mathrm{H}_{2} \mathrm{O}_{2}$ [95].

As previously mentioned (see Sects. 5.1.2 and 5.1.3), virulent $E$. histolytica trophozoites can probably resist the destructive action of NO, ROS, and peroxynitrite. The uniformity and low negative charge of the amebic surface coat are also an essential amebic defense mechanism. It can be appreciated that several self-defense mechanisms of amebas are apparently involved in a survival function, which if successful, triggers a prolonged inflammatory response by the host.

\section{Inflammation and hypoxia}

A host invasion by E. histolytica trophozoites provokes inflammation, which leads to vasodilation and induces hypoxia and ischemia in the early and late stages of amebic liver abscesses in susceptible (hamster) or resistant (mouse) species. Hypoxia (low oxygen) or anoxia (complete lack of oxygen), acidosis (high $\mathrm{H}+$ concentration), and abundant free oxygen radicals are characteristic features of inflamed tissues. Hence, the battle between neutrophils and pathogenic microorganisms, including Entamoeba, takes place mainly in hypoxic microenvironments [78].

Hypoxia is caused by decreased perfusion, increased interstitial pressure, microvascular injury, thrombosis, and the occlusion of blood vessel by amebas, coupled with the local consumption of $\mathrm{O}_{2}$ by parasites and recruited inflammatory cells [79, 81, 89, 123-125]. Thus, at inflammatory sites, ischemia contributes to tissue damage and decreases the exposure of trophozoites to serum components (especially the complement).

The relatively anaerobic microenvironment created is favorable for parasites [81]. However, it is also favorable for human neutrophils, because hypoxic conditions inhibit their rate of constitutive apoptosis [72] that could otherwise be triggered by amebic adherence and oxidation (see Sect. 1.1). For example, it has been reported that ROS-dependent neutrophil apoptosis is probably hampered when the neutrophils encounter E. histolytica in inflamed tissue in vivo [114], which could explain why neutrophils close to amebas remain viable, while those farther away (outside of the inflammatory focus) do not [125].

Hence, if neutrophils and other immune molecules cannot get rid of the host of E. histolytica during the early stages of amebic invasion, the massive lysing of neutrophils (outside of the inflammatory foci) by amebas apparently helps tip the balance in favor of the latter during the battle between the invader and its host. In an in vitro study [103], the interaction of neutrophils and amebas in the presence of Chang liver cells showed that the lysed neutrophils enhanced the destruction of the liver cell monolayer in a concentration-dependent manner. The authors concluded that the in vitro lysis of human neutrophils by E. histolytica enhances the destruction of liver tissue, probably through the release of neutrophil oxidative products.

\section{Conclusions}

Increasing evidence strongly suggests that liver abscesses are formed during amebiasis by mechanisms of host inflammatory response. Prolonged and exaggerated inflammation is triggered by amebas that are capable of surviving in the host environment. Hence, it seems that adequate host innate immune response, which would eliminate amebas and prevent chronic inflammation, is the key to avoiding ALA.

In the early stages of invasion, E. histolytica amebas are mainly surrounded by neutrophils and other cells of the host innate immune response. If properly activated, these immune cells are probably successful in eliminating amebas through oxidative and non-oxidative mechanisms, including neutrophil degranulation, the generation of free radicals $\left(\mathrm{O}_{2}{ }^{-}\right.$, $\mathrm{H}_{2} \mathrm{O}_{2}, \mathrm{HOCl}$ ) and peroxynitrite, the activation of NADPHoxidase and MPO enzymes, and the formation of NETs. Neutrophils are also involved in the regulation of other cells of the innate and adaptive immune responses. The battle between the invader and the host takes place within the hypoxic environment of inflammatory sites, which has favorable effects on both amebic and neutrophil function. Future studies are needed to deepen the understanding of the molecules and mechanisms involved in the pathogenesis of ALA in rodents and humans.

\section{Conflict of interest}

The authors declare that there is no conflict of interest regarding the publication of this paper.

Acknowledgements. Judith Pacheco-Yepez, Rosa Adriana JarilloLuna, Edgar Abarca-Rojano, and Rafael Campos-Rodríguez are fellows of COFAA-IPN and EDI-IPN. 


\section{References}

1. Abi Abdallah DS, Lin C, Ball CJ, King MR, Duhamel GE, Denkers EY. 2012. Toxoplasma gondii triggers release of human and mouse neutrophil extracellular traps. Infection and Immunity, 80(2), 768-777.

2. Aguirre-Garcia J. 1970. Histopathological peculiarities of the amebic lesion. Archivos de Investigacion Medica (Mex), 1(Suppl), 147-156.

3. Akbar MA, Chatterjee NS, Sen P, Debnath A, Pal A, Bera T, Das P. 2004. Genes induced by a high-oxygen environment in Entamoeba histolytica. Molecular and Biochemical Parasitology, 133(2), 187-196.

4. Al-Mofleh IA, Al-Tuwaijri AS, Mahmoud AA, Alam M. 1989. Entamoeba histolytica depresses chemiluminescence in stimulated human polymorphonuclear leukocytes. International Journal of Immunopharmacology, 11(5), 529-536.

5. Ali IK, Mondal U, Roy S, Haque R, Petri WA Jr., Clark CG. 2007. Evidence for a link between parasite genotype and outcome of infection with Entamoeba histolytica. Journal of Clinical Microbiology, 45(2), 285-289.

6. Amulic B, Cazalet C, Hayes GL, Metzler KD, Zychlinsky A. 2012. Neutrophil function: from mechanisms to disease. Annual Review of Immunology, 30, 459-489.

7. Ankri S, Padilla-Vaca F, Stolarsky T, Koole L, Katz U, Mirelman D. 1999. Antisense inhibition of expression of the light subunit $(35 \mathrm{kDa})$ of the $\mathrm{Gal} / \mathrm{GalNac}$ lectin complex inhibits Entamoeba histolytica virulence. Molecular Microbiology, 33(2), 327-337.

8. Arbo A, Hoefsloot M, Ramirez A, Ignacio Santos J. 1990. Entamoeba histolytica inhibits the respiratory burst of polymorphonuclear leukocytes. Archivos de Investigacion Medica (Mex), 21(Suppl 1), 57-61.

9. Arellano J, Isibasi A, Miranda R, Higuera F, Granados J, Kretschmer RR. 1987. HLA antigens associated to amoebic abscess of the liver in Mexican mestizos. Parasite Immunology, 9(6), 757-760.

10. Arellano J, Perez-Rodriguez M, Lopez-Osuna M, Velazquez JR, Granados J, Justiniani N, Santos JI, Madrazo A, Munoz L, Kretschmer R. 1996. Increased frequency of HLA-DR3 and complotype SCO1 in Mexican mestizo children with amoebic abscess of the liver. Parasite Immunology, 18(10), 491-498.

11. Arteel GE, Sies H. 1999. Protection against peroxynitrite by cocoa polyphenol oligomers. FEBS Letter, 462(1-2), 167-170.

12. Bainton DF. 1973. Sequential degranulation of the two types of polymorphonuclear leukocyte granules during phagocytosis of microorganisms. Journal of Cell Biology, 58(2), 249-264.

13. Baker VS, Imade GE, Molta NB, Tawde P, Pam SD, Obadofin MO, Sagay SA, Egah DZ, Iya D, Afolabi BB, Baker M, Ford K, Ford R, Roux KH, Keller TC 3rd. 2008. Cytokine-associated neutrophil extracellular traps and antinuclear antibodies in Plasmodium falciparum infected children under six years of age. Malaria Journal, 7, 41.

14. Berninghausen O, Leippe M. 1997. Necrosis versus apoptosis as the mechanism of target cell death induced by Entamoeba histolytica. Infection and Immunity, 65(9), 3615-3621.

15. Bhattacharya A, Prasad R, Sacks DL. 1992. Identification and partial characterization of a lipophosphoglycan from a pathogenic strain of Entamoeba histolytica. Molecular and Biochemical Parasitology, 56(1), 161-168.
16. Borregaard N, Sorensen OE, Theilgaard-Monch K. 2007. Neutrophil granules: a library of innate immunity proteins. Trends in Immunology, 28(8), 340-345.

17. Brinkmann V, Reichard U, Goosmann C, Fauler B, Uhlemann Y, Weiss DS, Weinrauch Y, Zychlinsky A. 2004. Neutrophil extracellular traps kill bacteria. Science, 303(5663), 1532-1535.

18. Bruchhaus I, Tannich E. 1994. Induction of the iron-containing superoxide dismutase in Entamoeba histolytica by a superoxide anion-generating system or by iron chelation. Molecular and Biochemical Parasitology, 67(2), 281-288.

19. Bruchhaus I, Tannich E. 1995. Identification of an Entamoeba histolytica gene encoding a protein homologous to prokaryotic disulphide oxidoreductases. Molecular and Biochemical Parasitology, 70(1-2), 187-191.

20. Bruchhaus I, Richter S, Tannich E. 1997. Removal of hydrogen peroxide by the $29 \mathrm{kDa}$ protein of Entamoeba histolytica. Biochemical Journal, 326(Pt 3), 785-789.

21. Bruchhaus I, Richter S, Tannich E. 1998. Recombinant expression and biochemical characterization of an NADPH:flavin oxidoreductase from Entamoeba histolytica. Biochemical Journal, 330(Pt 3), 1217-1221.

22. Bruchhaus I, Roeder T, Lotter H, Schwerdtfeger M, Tannich E. 2002. Differential gene expression in Entamoeba histolytica isolated from amoebic liver abscess. Molecular Microbiology, 44(4), 1063-1072.

23. Burchard GD, Bilke R. 1992. Adherence of pathogenic and non-pathogenic Entamoeba histolytica strains to neutrophils. Parasitology Research, 78(2), 146-153.

24. Campos-Rodriguezp R, Jarillo-Luna A. 2005. The pathogenicity of Entamoeba histolytica is related to the capacity of evading innate immunity. Parasite Immunology, 27(1-2), 1-8.

25. Campos-Rodriguez R, Jarillo-Luna RA, Larsen BA, RiveraAguilar V, Ventura-Juarez J. 2009. Invasive amebiasis: a microcirculatory disorder? Medical Hypotheses, 73(5), 687-697.

26. Cassatella MA. 1999. Neutrophil-derived proteins: selling cytokines by the pound. Advances in Immunology, 73, 369-509.

27. Chadee K, Meerovitch E. 1984. The Mongolian gerbil (Meriones unguiculatus) as an experimental host for Entamoeba histolytica. American Journal of Tropical Medicine and Hygiene, 33(1), 47-54.

28. Chadee K, Moreau F, Meerovitch E. 1987. Entamoeba histolytica: chemoattractant activity for gerbil neutrophils in vivo and in vitro. Experimental Parasitology, 64(1), 12-23.

29. Chertov O, Yang D, Howard OM, Oppenheim JJ. 2000. Leukocyte granule proteins mobilize innate host defenses and adaptive immune responses. Immunological Review, 177, 68-78.

30. Choi MH, Sajed D, Poole L, Hirata K, Herdman S, Torian BE, Reed SL. 2005. An unusual surface peroxiredoxin protects invasive Entamoeba histolytica from oxidant attack. Molecular and Biochemical Parasitology, 143(1), 80-89.

31. Christy NC, Petri WA Jr. 2011. Mechanisms of adherence, cytotoxicity and phagocytosis modulate the pathogenesis of Entamoeba histolytica. Future Microbiology, 6(12), 1501-1519.

32. Cieslak PR, Virgin HW, Stanley SL Jr. 1992. A severe combined immunodeficient (SCID) mouse model for infection with Entamoeba histolytica. Journal of Experimental Medicine, 176(6), 1605-1609. 
33. Costa CA, Brito KN, Gomes MA, Caliari MV. 2007. Morphometric study of the hepatic lesions experimentally induced in hamsters by Entamoeba dispar and Entamoeba histolytica. Parasite, 14(4), 329-334.

34. Davis PH, Zhang X, Guo J, Townsend RR, Stanley SL Jr. 2006. Comparative proteomic analysis of two Entamoeba histolytica strains with different virulence phenotypes identifies peroxiredoxin as an important component of amoebic virulence. Molecular Microbiology, 61(6), 1523-1532.

35. Denis M, Chadee K. 1989. Human neutrophils activated by interferon-gamma and tumour necrosis factor-alpha kill Entamoeba histolytica trophozoites in vitro. Journal of Leukocyte Biology, 46(3), 270-274.

36. Duggal P, Haque R, Roy S, Mondal D, Sack RB, Farr BM, Beaty TH, Petri WA Jr. 2004. Influence of human leukocyte antigen class II alleles on susceptibility to Entamoeba histolytica infection in Bangladeshi children. Journal of Infectious Diseases, 189(3), 520-526.

37. Faust DM, Guillen N. 2012. Virulence and virulence factors in Entamoeba histolytica, the agent of human amoebiasis. Microbes and Infection, 14(15), 1428-1441.

38. Fuchs TA, Abed U, Goosmann C, Hurwitz R, Schulze I, Wahn V, Weinrauch Y, Brinkmann V, Zychlinsky A. 2007. Novel cell death program leads to neutrophil extracellular traps. Journal of Cell Biology, 176(2), 231-241.

39. Gabriel C, McMaster WR, Girard D, Descoteaux A. 2010. Leishmania donovani promastigotes evade the antimicrobial activity of neutrophil extracellular traps. Journal of Immunology, 185(7), 4319-4327.

40. Gelderman MP, Stuart R, Vigerust D, Fuhrmann S, Lefkowitz DL, Allen RC, Lefkowitz SS, Graham S. 1998. Perpetuation of inflammation associated with experimental arthritis: the role of macrophage activation by neutrophilic myeloperoxidase. Mediators of Inflammation, 7(6), 381-389.

41. Ghadirian E, Somerfield SD, Kongshavn PA. 1986. Susceptibility of Entamoeba histolytica to oxidants. Infection and Immunity, 51(1), 263-267.

42. Ghosh AS, Dutta S, Raha S. 2010. Hydrogen peroxide-induced apoptosis-like cell death in Entamoeba histolytica. Parasitology International, 59(2), 166-172.

43. Grattendick K, Stuart R, Roberts E, Lincoln J, Lefkowitz SS, Bollen A, Moguilevsky N, Friedman H, Lefkowitz DL. 2002. Alveolar macrophage activation by myeloperoxidase: a model for exacerbation of lung inflammation. American Journal of Respiratory Cell and Molecular Biology, 26(6), 716-722.

44. Guerrant RL, Brush J, Ravdin JI, Sullivan JA, Mandell GL. 1981. Interaction between Entamoeba histolytica and human polymorphonuclear neutrophils. Journal of Infectious Diseases, 143(1), 83-93.

45. Guimaraes-Costa AB, Nascimento MT, Froment GS, Soares RP, Morgado FN, Conceicao-Silva F, Saraiva EM. 2009. Leishmania amazonensis promastigotes induce and are killed by neutrophil extracellular traps. Proceedings of the National Academy of Sciences of the United States of America, 106(16), 6748-6753.

46. Guo X, Houpt E, Petri WA Jr. 2007. Crosstalk at the initial encounter: interplay between host defense and ameba survival strategies. Current Opinion in Immunology, 19(4), 376-384.

47. Hampton MB, Kettle AJ, Winterbourn CC. 1998. Inside the neutrophil phagosome: oxidants, myeloperoxidase, and bacterial killing. Blood, 92(9), 3007-3017.
48. Helk E, Bernin H, Ernst T, Ittrich H, Jacobs T, Heeren J, Tacke F, Tannich E, Lotter H. 2013. TNFalpha-mediated liver destruction by Kupffer cells and Ly6Chi monocytes during Entamoeba histolytica infection. PLoS Pathogen, 9(1), e1003096.

49. Hermosilla C, Caro TM, Silva LM, Ruiz A, Taubert A. 2014. The intriguing host innate immune response: novel antiparasitic defence by neutrophil extracellular traps. Parasitology, 141(11), 1489-1498.

50. Hernandez EG, Granados J, Partida-Rodriguez O, Valenzuela O, Rascon E, Magana U, Escamilla-Tilch M, Lopez-Reyes A, Nieves-Ramirez M, Gonzalez E, Moran P, Rojas L, Valadez A, Luna A, Estrada FJ, Maldonado C, Ximenez C. 2015. Prevalent HLA class II alleles in Mexico city appear to confer resistance to the development of amebic liver abscess. PLoS One, 10(5), e0126195.

51. Horstmann RD, Leippe M, Tannich E. 1992. Host tissue destruction by Entamoeba histolytica: molecules mediating adhesion, cytolysis, and proteolysis. Memórias do Instituto Oswaldo Cruz, 87(Suppl 5), 57-60.

52. Irmer H, Tillack M, Biller L, Handal G, Leippe M, Roeder T, Tannich E, Bruchhaus I. 2009. Major cysteine peptidases of Entamoeba histolytica are required for aggregation and digestion of erythrocytes but are dispensable for phagocytosis and cytopathogenicity. Molecular Microbiology, 72(3), 658-667.

53. Jarillo-Luna RA, Campos-Rodriguez R, Tsutsumi V. 2002. Entamoeba histolytica: immunohistochemical study of hepatic amoebiasis in mouse. Neutrophils and nitric oxide as possible factors of resistance. Experimental Parasitology, 101(1), 40-56.

54. Keene WE, Petitt MG, Allen S, McKerrow JH. 1986. The major neutral proteinase of Entamoeba histolytica. Journal of Experimental Medicine, 163(3), 536-549.

55. Klebanoff SJ. 1999. Myeloperoxidase. Proceedings of the Association of American Physicians, 111(5), 383-389.

56. Klebanoff SJ. 2005. Myeloperoxidase: friend and foe. Journal of Leukocyte Biology, 77(5), 598-625.

57. Klotz LO, Sies H. 2003. Defenses against peroxynitrite: selenocompounds and flavonoids. Toxicology Letters, 140-141, $125-132$.

58. Kretschmer R, Collado ML, Pacheco MG, Salinas MC, LopezOsuna M, Lecuona M, Castro EM, Arellano J. 1985. Inhibition of human monocyte locomotion by products of axenically grown Entamoeba histolytica. Parasite Immunology, 7(5), 527-543.

59. Kumar V, Sharma A. 2010. Neutrophils: Cinderella of innate immune system. International Immunopharmacology, 10(11), $1325-1334$.

60. Lefkowitz DL, Lefkowitz SS. 2008. Microglia and myeloperoxidase: a deadly partnership in neurodegenerative disease. Free Radical Biology and Medicine, 45(5), 726-731.

61. Levy O. 2004. Antimicrobial proteins and peptides: antiinfective molecules of mammalian leukocytes. Journal of Leukocyte Biology, 76(5), 909-925.

62. Lin JY, Seguin R, Keller K, Chadee K. 1995. Transforming growth factor-beta 1 primes macrophages for enhanced expression of the nitric oxide synthase gene for nitric oxidedependent cytotoxicity against Entamoeba histolytica. Immunology, 85(3), 400-407.

63. Lotter H, Jacobs T, Gaworski I, Tannich E. 2006. Sexual dimorphism in the control of amebic liver abscess in a mouse model of disease. Infection and Immunity, 74(1), 118-124.

64. Lotter H, Gonzalez-Roldan N, Lindner B, Winau F, Isibasi A, Moreno-Lafont M, Ulmer AJ, Holst O, Tannich E, Jacobs T. 
2009. Natural killer T cells activated by a lipopeptidophosphoglycan from Entamoeba histolytica are critically important to control amebic liver abscess. PLoS Pathogens, 5(5), e1000434.

65. Lotter H, Helk E, Bernin H, Jacobs T, Prehn C, Adamski J, Gonzalez-Roldan N, Holst O, Tannich E. 2013. Testosterone increases susceptibility to amebic liver abscess in mice and mediates inhibition of IFNgamma secretion in natural killer T cells. PLoS One, 8(2), e55694.

66. Maldonado-Bernal C, Kirschning CJ, Rosenstein Y, Rocha LM, Rios-Sarabia N, Espinosa-Cantellano M, Becker I, Estrada I, Salazar-Gonzalez RM, Lopez-Macias C, Wagner H, Sanchez J, Isibasi A. 2005. The innate immune response to Entamoeba histolytica lipopeptidophosphoglycan is mediated by toll-like receptors 2 and 4. Parasite Immunology, 27(4), 127-137.

67. Maldonado C, Trejo W, Ramirez A, Carrera M, Sanchez J, Lopez-Macias C, Isibasi A. 2000. Lipophosphopeptidoglycan of Entamoeba histolytica induces an antiinflammatory innate immune response and downregulation of toll-like receptor 2 (TLR-2) gene expression in human monocytes. Archives of Medical Research, 31(4 Suppl), S71-S73.

68. Maralikova B, Ali V, Nakada-Tsukui K, Nozaki T, van der Giezen M, Henze K, Tovar J. 2010. Bacterial-type oxygen detoxification and iron-sulfur cluster assembly in amoebal relict mitochondria. Cellular Microbiology, 12(3), 331-342.

69. Marie C, Petri WA Jr. 2014. Regulation of virulence of Entamoeba histolytica. Annual Review of Microbiology, 68, 493-520.

70. Matthiesen J, Bar AK, Bartels AK, Marien D, Ofori S, Biller L, Tannich E, Lotter H, Bruchhaus I. 2013. Overexpression of specific cysteine peptidases confers pathogenicity to a nonpathogenic Entamoeba histolytica clone. MBio, 4(2), e00072-13.

71. Mayer-Scholl A, Averhoff P, Zychlinsky A. 2004. How do neutrophils and pathogens interact? Current Opinion in Microbiology, 7(1), 62-66.

72. Mecklenburgh KI, Walmsley SR, Cowburn AS, Wiesener M, Reed BJ, Upton PD, Deighton J, Greening AP, Chilvers ER. 2002. Involvement of a ferroprotein sensor in hypoxia-mediated inhibition of neutrophil apoptosis. Blood, 100(8), 30083016.

73. Metzler KD, Fuchs TA, Nauseef WM, Reumaux D, Roesler J, Schulze I, Wahn V, Papayannopoulos V, Zychlinsky A. 2011. Myeloperoxidase is required for neutrophil extracellular trap formation: implications for innate immunity. Blood, 117(3), 953-959.

74. Moran P, Rico G, Ramiro M, Olvera H, Ramos F, Gonzalez E, Valadez A, Curiel O, Melendro EI, Ximenez C. 2002. Defective production of reactive oxygen intermediates (ROI) in a patient with recurrent amebic liver abscess. American Journal of Tropical Medicine and Hygiene, 67(6), 632-635.

75. Mortimer L, Chadee K. 2010. The immunopathogenesis of Entamoeba histolytica. Experimental Parasitology, 126(3), 366-380.

76. Murray HW, Aley SB, Scott WA. 1981. Susceptibility of Entamoeba histolytica to oxygen intermediates. Molecular and Biochemical Parasitology, 3(6), 381-391.

77. Nathan C. 2006. Neutrophils and immunity: challenges and opportunities. Nature Reviews Immunology, 6(3), 173-182.

78. Nizet V, Johnson RS. 2009. Interdependence of hypoxic and innate immune responses. Nature Reviews Immunology, 9(9), 609-617.

79. Olivos-Garcia A, Nequiz-Avendano M, Tello E, Martinez RD, Gonzalez-Canto A, Lopez-Vancell R, Garcia de Leon MC,
Montfort I, Perez-Tamayo R. 2004. Inflammation, complement, ischemia and amoebic survival in acute experimental amoebic liver abscesses in hamsters. Experimental and Molecular Pathology, 77(1), 66-71.

80. Olivos-Garcia A, Carrero JC, Ramos E, Nequiz M, Tello E, Montfort I, Perez-Tamayo R. 2007. Late experimental amebic liver abscess in hamster is inhibited by cyclosporine and N-acetylcysteine. Experimental and Molecular Pathology, 82(3), 310-315.

81. Olivos-Garcia A, Saavedra E, Ramos-Martinez E, Nequiz M, Perez-Tamayo R. 2009. Molecular nature of virulence in Entamoeba histolytica. Infection, Genetics and Evolution, 9(6), 1033-1037.

82. Pacheco-Yepez J, Campos-Rodriguez R, Shibayama M, Ventura-Juarez J, Serrano-Luna J, Tsutsumi V. 2001. Entamoeba histolytica: production of nitric oxide and in situ activity of NADPH diaphorase in amebic liver abscess of hamsters. Parasitology Research, 87(1), 49-56.

83. Pacheco-Yepez J, Rivera-Aguilar V, Barbosa-Cabrera E, Rojas Hernandez S, Jarillo-Luna RA, Campos-Rodriguez R. 2011. Myeloperoxidase binds to and kills Entamoeba histolytica trophozoites. Parasite Immunology, 33(5), 255-264.

84. Pacheco-Yepez J, Jarillo-Luna RA, Gutierrez-Meza M, AbarcaRojano E, Larsen BA, Campos-Rodriguez R. 2014. Peroxynitrite and peroxiredoxin in the pathogenesis of experimental amebic liver abscess. BioMed Research International, 2014, 324230 .

85. Papayannopoulos V, Zychlinsky A. 2009. NETs: a new strategy for using old weapons. Trends in Immunology, 30(11), 513-521.

86. Papayannopoulos V, Metzler KD, Hakkim A, Zychlinsky A. 2010. Neutrophil elastase and myeloperoxidase regulate the formation of neutrophil extracellular traps. Journal of Cell Biology, 191(3), 677-691.

87. Parker H, Dragunow M, Hampton MB, Kettle AJ, Winterbourn CC. 2012. Requirements for NADPH oxidase and myeloperoxidase in neutrophil extracellular trap formation differ depending on the stimulus. Journal of Leukocyte Biology, 92(4), 841-849.

88. Perez-Tamayo R, Becker I, Martinez RD, Olivos A, Montfort I, Perez-Montfort R. 1990. The mechanism of natural resistance in the rat to Entamoeba histolytica. Archivos de Investigacion Medica (Mex), 21(Suppl 1), 157-161.

89. Perez-Tamayo R, Montfort I, Tello E, Olivos A. 1992. Ischemia in experimental acute amebic liver abscess in hamsters. International Journal for Parasitology, 22(1), 125-129.

90. Perez-Tamayo R, Montfort I, Garcia AO, Ramos E, Ostria CB. 2006. Pathogenesis of acute experimental liver amebiasis. Archives of Medical Research, 37(2), 203-209.

91. Podrez EA, Abu-Soud HM, Hazen SL. 2000. Myeloperoxidasegenerated oxidants and atherosclerosis. Free Radical Biology and Medicine, 28(12), 1717-1725.

92. Ralston KS, Petri WA. 2011. The ways of a killer: how does Entamoeba histolytica elicit host cell death? Essays in Biochemistry, 51, 193-210.

93. Ralston KS, Petri WA Jr. 2011. Tissue destruction and invasion by Entamoeba histolytica. Trends in Parasitology, 27(6), 254-263.

94. Ramirez-Emiliano J, Gonzalez-Hernandez A, Arias-Negrete S. 2005. Expression of inducible nitric oxide synthase mRNA and nitric oxide production during the development of liver abscess in hamster inoculated with Entamoeba histolytica. Current Microbiology, 50(6), 299-308. 
95. Ramos-Martinez E, Olivos-Garcia A, Saavedra E, Nequiz M, Sanchez EC, Tello E, El-Hafidi M, Saralegui A, Pineda E, Delgado J, Montfort I, Perez-Tamayo R. 2009. Entamoeba histolytica: oxygen resistance and virulence. International Journal for Parasitology, 39(6), 693-702.

96. Ramos E, Olivos-Garcia A, Nequiz M, Saavedra E, Tello E, Saralegui A, Montfort I, Perez Tamayo R. 2007. Entamoeba histolytica: apoptosis induced in vitro by nitric oxide species. Experimental Parasitology, 116(3), 257-265.

97. Ravdin JI, Murphy CF, Salata RA, Guerrant RL, Hewlett EL. 1985. N-Acetyl-D-galactosamine-inhibitable adherence lectin of Entamoeba histolytica. I. Partial purification and relation to amoebic virulence in vitro. Journal of Infectious Diseases, 151(5), 804-815.

98. Reed SL, Gigli I. 1990. Lysis of complement-sensitive Entamoeba histolytica by activated terminal complement components. Initiation of complement activation by an extracellular neutral cysteine proteinase. Journal of Clinical Investigation, 86(6), 1815-1822.

99. Reed SL, Keene WE, McKerrow JH, Gigli I. 1989. Cleavage of C3 by a neutral cysteine proteinase of Entamoeba histolytica. Journal of Immunology, 143(1), 189-195.

100. Reeves EP, Lu H, Jacobs HL, Messina CG, Bolsover S, Gabella G, Potma EO, Warley A, Roes J, Segal AW. 2002. Killing activity of neutrophils is mediated through activation of proteases by $\mathrm{K}+$ flux. Nature, 416(6878), 291-297.

101. Riahi Y, Siman-Tov R, Ankri S. 2004. Molecular cloning, expression and characterization of a serine proteinase inhibitor gene from Entamoeba histolytica. Molecular and Biochemical Parasitology, 133(2), 153-162.

102. Roberts TH, Hejgaard J, Saunders NF, Cavicchioli R, Curmi PM. 2004. Serpins in unicellular Eukarya, Archaea, and Bacteria: sequence analysis and evolution. Journal of Molecular Evolution, 59(4), 437-447.

103. Salata RA, Ravdin JI. 1986. The interaction of human neutrophils and Entamoeba histolytica increases cytopathogenicity for liver cell monolayers. Journal of Infectious Diseases, 154(1), 19-26.

104. Salata RA, Ravdin JI. 1988. The interaction of polymorphonuclear neutrophils and Entamoeba histolytica, in Amebiasis, Human infection by Entamoeba histolytica. Ravdin JI, Editor. Churchill Livingston: New York. p. 464-470.

105. Salata RA, Ahmed P, Ravdin JI. 1989. Chemoattractant activity of Entamoeba histolytica for human polymorphonuclear neutrophils. Journal of Parasitology, 75(4), 644-646.

106. Santi-Rocca J, Rigothier MC, Guillen N. 2009. Host-microbe interactions and defense mechanisms in the development of amoebic liver abscesses. Clinical Microbiology Reviews, 22(1), 65-75.

107. Segal AW. 2005. How neutrophils kill microbes. Annual Review of Immunology, 23, 197-223.

108. Segal AW. 2008. The function of the NADPH oxidase of phagocytes and its relationship to other NOXs in plants, invertebrates, and mammals. International Journal of Biochemistry and Cell Biology, 40(4), 604-618.

109. Seydel KB, Zhang T, Stanley SL Jr. 1997. Neutrophils play a critical role in early resistance to amebic liver abscesses in severe combined immunodeficient mice. Infection and Immunity, 65(9), 3951-3953.

110. Seydel KB, Smith SJ, Stanley SL Jr. 2000. Innate immunity to amebic liver abscess is dependent on gamma interferon and nitric oxide in a murine model of disease. Infection and Immunity, 68(1), 400-402.

111. Shepherd VL, Hoidal JR. 1990. Clearance of neutrophilderived myeloperoxidase by the macrophage mannose receptor. American Journal of Respiratory Cell and Molecular Biology, 2(4), 335-340.

112. Shibayama M, Campos-Rodriguez R, Ramirez-Rosales A, Flores-Romo L, Espinosa-Cantellano M, Martinez-Palomo A, Tsutsumi V. 1998. Entamoeba histolytica: liver invasion and abscess production by intraperitoneal inoculation of trophozoites in hamsters, Mesocricetus auratus. Experimental Parasitology, 88(1), 20-27.

113. Shibayama M, Rivera-Aguilar V, Barbosa-Cabrera E, RojasHernandez S, Jarillo-Luna A, Tsutsumi V, Pacheco-Yepez J, Campos-Rodriguez R. 2008. Innate immunity prevents tissue invasion by Entamoeba histolytica. Canadian Journal Microbiology, 54(12), 1032-1042.

114. Sim S, Yong TS, Park SJ, Im KI, Kong Y, Ryu JS, Min DY, Shin MH. 2005. NADPH oxidase-derived reactive oxygen species-mediated activation of ERK1/2 is required for apoptosis of human neutrophils induced by Entamoeba histolytica. Journal of Immunology, 174(7), 4279-4288.

115. Soehnlein O. 2009. An elegant defense: how neutrophils shape the immune response. Trends in Immunology, 30(11), 511-512.

116. Soehnlein O, Lindbom L. 2010. Phagocyte partnership during the onset and resolution of inflammation. Nature Reviews Immunology, 10(6), 427-439.

117. Stanley SL. 2001. Pathophysiology of amoebiasis. Trends in Parasitology, 17(6), 280-285.

118. Stanley SL Jr. 2003. Amoebiasis. Lancet, 361(9362), 1025-1034.

119. Stanley SL Jr, Reed SL. 2001. Microbes and microbial toxins: paradigms for microbial-mucosal interactions. VI. Entamoeba histolytica: parasite-host interactions. American Journal of Physiology Gastrointestinal and Liver Physiology, 280(6), G1049-G1054.

120. Szabo C, Ischiropoulos H, Radi R. 2007. Peroxynitrite: biochemistry, pathophysiology and development of therapeutics. Nature Reviews Drug Discovery, 6(8), 662-680.

121. Thrasher AJ, Segal AW. 2011. A phagocyte dilemma. Nature Immunology, 12(3), 201-202.

122. Tseng CW, Liu GY. 2014. Expanding roles of neutrophils in aging hosts. Current Opinion in Immunology, 29C, 43-48.

123. Tsutsumi V, Martinez-Palomo A. 1988. Inflammatory reaction in experimental hepatic amebiasis. An ultrastructural study. American Journal of Pathology, 130(1), 112-119.

124. Tsutsumi V, Shibayama M. 2006. Experimental amebiasis: a selected review of some in vivo models. Archives of Medical Research, 37(2), 210-220.

125. Tsutsumi V, Mena-Lopez R, Anaya-Velazquez F, MartinezPalomo A. 1984. Cellular bases of experimental amebic liver abscess formation. American Journal of Pathology, 117(1), 81-91.

126. Uhlmann D, Pietsch UC, Ludwig S, Hess J, Armann B, Gaebel G, Escher E, Schaffranietz L, Tannapfel A, Fiedler M, Hauss J, Witzigmann H. 2004. Assessment of hepatic ischemia-reperfusion injury by simultaneous measurement of tissue pO2, pCO2, and $\mathrm{pH}$. Microvascular Research, 67(1), 38-47.

127. Urban CF, Lourido S, Zychlinsky A. 2006. How do microbes evade neutrophil killing? Cellular Microbiology, 8(11), 1687-1696. 
128. Velazquez C, Shibayama-Salas M, Aguirre-Garcia J, Tsutsumi V, Calderon J. 1998. Role of neutrophils in innate resistance to Entamoeba histolytica liver infection in mice. Parasite Immunology, 20(6), 255-262.

129. Ventura-Juarez J, Jarillo-Luna RA, Fuentes-Aguilar E, PinedaVazquez A, Munoz-Fernandez L, Madrid-Reyes JI, CamposRodriguez R. 2003. Human amoebic hepatic abscess: in situ interactions between trophozoites, macrophages, neutrophils and T cells. Parasite Immunology, 25(10), 503-511.
130. Wartha F, Beiter K, Normark S, Henriques-Normark B. 2007. Neutrophil extracellular traps: casting the NET over pathogenesis. Current Opinion of Microbiology, 10(1), 52-56.

131. Wong-Baeza I, Alcantara-Hernandez M, Mancilla-Herrera I, Ramirez-Saldivar I, Arriaga-Pizano L, Ferat-Osorio E, LopezMacias C, Isibasi A. 2010. The role of lipopeptidophosphoglycan in the immune response to Entamoeba histolytica. Journal of Biomedicine and Biotechnology, 2010, 254521.

Cite this article as: Campos-Rodríguez R, Gutiérrez-Meza M, Jarillo-Luna RA, Drago-Serrano ME, Abarca-Rojano E, Ventura-Juárez J, Cárdenas-Jaramillo LM \& Pacheco-Yepez J: A review of the proposed role of neutrophils in rodent amebic liver abscess models. Parasite, 2016, 23, 6 .

\section{O PARASTE}

An international open-access, peer-reviewed, online journal publishing high quality papers on all aspects of human and animal parasitology

Reviews, articles and short notes may be submitted. Fields include, but are not limited to: general, medical and veterinary parasitology; morphology, including ultrastructure; parasite systematics, including entomology, acarology, helminthology and protistology, and molecular analyses; molecular biology and biochemistry; immunology of parasitic diseases; host-parasite relationships; ecology and life history of parasites; epidemiology; therapeutics; new diagnostic tools.

All papers in Parasite are published in English. Manuscripts should have a broad interest and must not have been published or submitted elsewhere. No limit is imposed on the length of manuscripts.

Parasite (open-access) continues Parasite (print and online editions, 1994-2012) and Annales de Parasitologie Humaine et Comparée (1923-1993) and is the official journal of the Société Française de Parasitologie. 